\title{
Precision medicine in cancer: challenges and recommendations from an EU-funded cervical cancer biobanking study
}

Sanne Samuels ${ }^{1}$, Balazs Balint ${ }^{2}$, Heiko von der Leyen ${ }^{3}$, Philippe Hupé ${ }^{6,7}$, Leanne de Koning ${ }^{8}$, Choumouss Kamoun ${ }^{9}$, Windy Luscap-Rondof ${ }^{9}$, Ulrike Wittkop ${ }^{3}$, Ksenia Bagrintseva ${ }^{4}$, Marina Popovic ${ }^{10}$, Atttila Kereszt ${ }^{2}$, Els Berns ${ }^{11}$, Gemma G Kenter ${ }^{1}$, Ekaterina S Jordanova ${ }^{12}$, Maud Kamal ${ }^{4}$ and Susy Scholl ${ }^{\star}, 4$ ${ }^{1}$ Centrum voor Gynaecologische Oncologie Amsterdam (CGOA), Department of Gynaecology, Netherlands Cancer Institute-Antoni van Leeuwenhoek, PO Box 90203, 1006 BE Amsterdam, The Netherlands; ${ }^{2}$ SeqOmics Biotechnology Itd, Vállalkozók útja 7, 6782 Mórahalom, Hungary; ${ }^{3}$ Hannover Clinical Trial Centre (HCTC) GmbH, Carl-Neuberg-Straße 1, 30625 Hannover, Germany; ${ }^{4}$ Department of Medical Oncology, Institut Curie, 26 Rue d'Ulm, 75248 Paris, France; ${ }^{5}$ INSERM, 101 Rue de Tolbiac, 75013 Paris, France; ${ }^{6}$ Department of Bioinformatics Institut Curie, Mines ParisTech, 60 Boulevard Saint-Michel, 75006 Paris, France; ${ }^{7}$ CNRS UMR 144, 26 Rue d'Ulm, 75248 Paris, France; ${ }^{8}$ Department of Translational Research, Institut Curie, 26 Rue d'Ulm, 75248 Paris, France; ${ }^{9}$ Department of Bioinformatics, Institut Curie, 26 Rue d'Ulm, 75005 Paris, France; ${ }^{10}$ Department of Gynaecology, Institut of Oncology of Vojvodina (IOV), Put Doktora Goldmana 4, 21204 Sremska Kamenica, Serbia; ${ }^{11}$ Department of Medical Oncology, Erasmus MC Cancer Institute, 's-Gravendijkwal 230, 3015 CE Rotterdam, The Netherlands and ${ }^{12}$ Centrum voor Gynaecologische Oncologie Amsterdam (CGOA), Department of Obstetrics and Gynaecology, VU University Medical Centre, De Boelelaan 1117, 1081 HV Amsterdam, The Netherlands

Background: Cervical cancer (CC) remains a leading cause of gynaecological cancer-related mortality worldwide. CC pathogenesis is triggered when human papillomavirus (HPV) inserts into the genome, resulting in tumour suppressor gene inactivation and oncogene activation. Collecting tumour and blood samples is critical for identifying these genetic alterations.

Methods: BIO-RAIDs is the first prospective molecular profiling clinical study to include a substantial biobanking effort that used uniform high-quality standards and control of samples. In this European Union (EU)-funded study, we identified the challenges that were impeding the effective implementation of such a systematic and comprehensive biobanking effort.

Results: The challenges included a lack of uniform international legal and ethical standards, complexities in clinical and molecular data management, and difficulties in determining the best technical platforms and data analysis techniques. Some difficulties were encountered by all investigators, while others affected only certain institutions, regions, or countries.

Conclusions: The results of the BIO-RAIDs programme highlight the need to facilitate and standardise regulatory procedures, and we feel that there is also a need for international working groups that make recommendations to regulatory bodies, governmental funding agencies, and academic institutions to achieve a proficient biobanking programme throughout EU countries. This represents the first step in precision medicine.

Cervical cancer (CC) remains the fourth leading cause of cancerrelated deaths in women worldwide (Ferlay et al, 2015), and there have been no marked therapeutic innovations in recent decades.
A recent review found only minor improvements in survival across cancer types (Prasad, 2016), despite the fact that more than 70 new cancer drugs were approved by the FDA between 2002 and 2014.

*Correspondence: Dr S Scholl; E-mail: suzy.scholl@gmail.com

Received 30 May 2016; revised 16 September 2016; accepted 21 September 2016; published online 22 November 2016

(c) 2016 Cancer Research UK. All rights reserved 0007 - 0920/16 
Nonetheless, some recent drugs, particularly when used in combination, showed promising results in selected cancers (Furue and Kadono, 2016). Many precision medicine trials are currently ongoing; they involve (1) the addition of targeted therapies to standard therapies according to specific single molecular alterations and/or tumour types and (2) algorithm testing in late-stage tumour types (Le Tourneau et al, 2014). The latter programs imply well-defined biobanking procedures for tumour, blood, sera and blood collection a prerequisite for precise and reproducible molecular results. Feedback on prospective biobanking experiences and challenges are starting to be reported with relevant standard operating procedures (SOPs; Diaz et al, 2013; Riondino et al, 2015). Results, available from the prospective 'SHIVA' trial conducted at the Institut Curie, turned out negative for the primary endpoint. Single drug usage in advanced disease is thought to be a reason for this overall negative result. However, it was concluded that administration of targeted therapies in latestage patients, used outside of their usual indications, might still be a valid approach to prolonging disease-free survival in subgroups of patients, in particular those harbouring a molecular alteration in the MEK/RAF signalling pathway (Le Tourneau et al, 2015).

We have focused on CC, where biopsies can be easily obtained. Molecular studies of $\mathrm{CC}$ are relevant for evaluating cancer pathogenesis as a dynamic multistep process that includes continuous genetic diversification, clonal expansion and selection. Essential genetic alterations in CC (and to $1 / 3$ of HNSCC) are virtually always kicked off by the insertion of pathogenic HPV s leading to abnormal activation of oncogenes and/or the inactivation of tumour suppressor genes. These alterations can be detected using a range of techniques (Le Tourneau et al, 2016). The International Cancer Genome Consortium (ICGC) studied more than 25000 cancer genomes from patients with 50 different cancer types and identified the most frequent gene copy number variations, translocations, and point mutations to determine those that can be considered 'druggable' therapeutic targets (International Cancer Genome et al, 2010). When we started this clinical trial, no prospective data set studying the relevance of molecular alterations in CC outcome was available.

Owing to the well-known high intra-tumour heterogeneity of genetic alterations, there have been few recent clinical breakthroughs in any cancer. It has been suggested that neo-antigens, which potentially influence immune surveillance, may arise in parallel with genetic alterations (Marusyk et al, 2012; McGranahan et al, 2016), presenting opportunities for immunological targeting. Although treatment using molecular stratifications has not been attempted systematically in CC, differential mutational and gene expression patterns are associated with squamous or adenocarcinoma CC histopathological types (Schwarz et al, 2012; Scholl et al, 2013; Jimenez-Wences et al, 2014; Ojesina et al, 2014; Rusan et al, 2015; Spaans et al, 2015). In retrospective data sets of CC and head and neck tumours combined, three subgroups of pathway alterations were revealed in human papillomavirus (HPV)associated cancer: namely cell proliferation/survival, immune response/cell death, and cellular differentiation (Rusan et al, 2015).

BIO-RAIDs, a prospective study of patients with previously non-treated CC (stages IB1-IV), was initiated in seven European countries with the aim of analysing primary tumours at the molecular level along with patient outcome to stratify tumours into classes according to the underlying pathway activation and prognosis. Preliminary bioinformatics analysis using ACSN (Atlas of Cancer Signalling Networks), which was based on TCGA, Ojesina (Ojesina et $a l, 2014)$ and the first exome sequencing data from the first 48 BIO-RAIDs patients, suggested that CC can be stratified into 5 classes with distinct molecular features (unpublished data). At the time of manuscript submission, BIO-RAIDs had recruited over 400 patients. The BIO-RAIDs protocol was published previously (Ngo et al, 2015).
Here we present the challenges for molecular assessment studies that were identified during this systematic biobanking and provide recommendations for conducting similar studies in the future. The identified challenges were related to: diversity of legal and ethical standards in different countries, lack of clinical trial resources at some centres, lack of experience in biobanking in many centres, and to the complexity integrating molecular data on multiple samples (Figure 1). Clear guidelines are needed to perform a coherent and reproducible molecular analysis of tumours and to guide appropriate clinical trials. Our hope is that BIO-RAIDs will set the stage for future precision medicine studies by international groups.

CHALLENGES AND SUGGESTED RECOMMENDATIONS FOR FUTURE BIOBANKING STUDIES

Delays in regulatory approval before the initiation of clinical trials. One of the major challenges encountered was that the study protocol was perceived differently by the participating European countries, and variations in regulatory aspects in the countries involved complicated the initiation of the clinical trial (Table 1). In some countries, BIO-RAIDs was considered an interventional study due to the request for iterative biopsies and blood sampling. In contrast, other countries considered it a non-interventional study since it did not modify standard treatment procedures. This classification impacted insurance fees and caused delays in contracting. Furthermore, in some countries, any biobanking study requires clinical study insurance, regardless of whether it is labelled 'interventional'. Insurance costs vary according to the number of patients, the risk of participating in the study, and protocol timelines. The variations in insurance fees were quite large, despite leverage between insurance agencies, and in particular the costs depended on whether the insurer had to insure patients outside of his home country. The timelines for contract negotiation between Sponsors (or Sponsor Delegates) and the different clinical sites depended on approval by the Boards of Directors of the hospitals involved. Protracted discussions about the types of responsibilities that were delegated to Sponsors or Sponsor Delegates included a detailed scrutiny of all monitoring tasks to minimise personmonths and therefore costs. One issue was the definition of the lieu to settle disputes in court and the absence of an established international rule concerning this matter. For BIO-RAIDs, it was decided that any dispute would be settled in accordance with the national law in the defendant's country. Lengthy procedures for reimbursing subcontracted tasks by administrations in highincome countries to contract research organisations in lowerincome countries were discouraging for both the clinical investigators and for the subcontracted support structures.

Recommendations for speeding up clinical trial initiation. Clearer European guidelines and common legislation would be helpful for future prospective studies that are 'without an experimental drug'. The new European regulation, European Union (EU) No. 536/2014, provides some modified regulatory requirements for low-interventional trials. Similar directives are urgently needed for biobanking studies which have minimal or no added risk for the patients. Sampling and biobanking are routine procedures in qualified hospitals and might ideally be part of the institutional coverage. The need for additional insurance for biobanking leading to targeted therapy trials should be examined further. Standard European guidelines for contracting between partners in clinical trials would be advantageous. Both operational and financial autonomy for heads of clinical support structures in larger hospitals/scientific administrations is important to expedite the implementation of new trials and reduce the time-to-site initiation. 


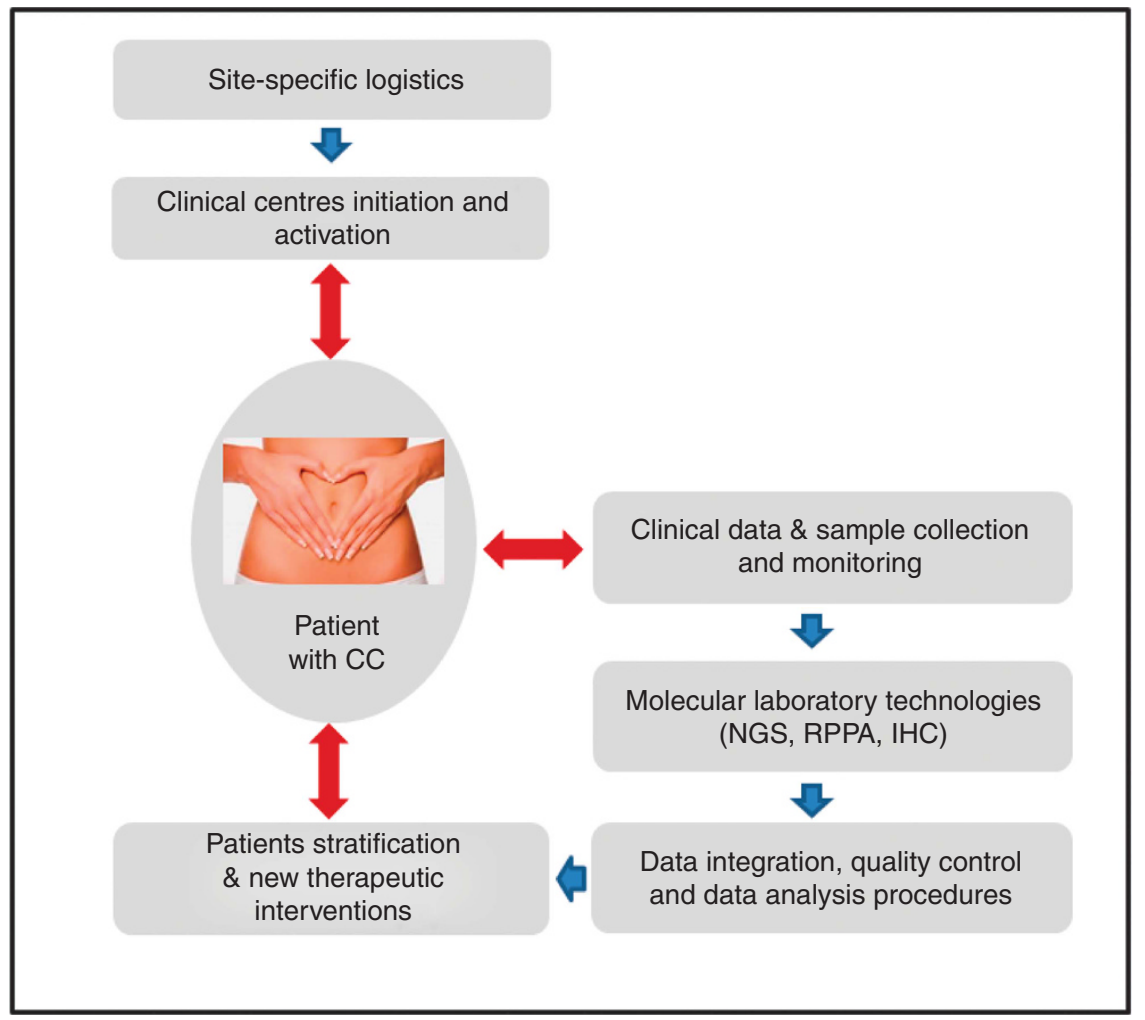

Figure 1. An overview of the critical challenges for performing prospective biobanking studies.

\section{Table 1. Delays in regulatory approval before the initiation of clinical trials}

\begin{tabular}{|l|l|l|l|}
\hline $\begin{array}{l}\text { Management of } \\
\text { clinical study }\end{array}$ & Challenges & Specific challenges & Recommendations \\
\hline Clinical site selection & $\begin{array}{l}\text { Regulary qualification } \\
\text { Pre-study visits and qualification of sites: } \\
\text { France, Serbia } \\
\text { investment of manpower and budget: time } \\
\text { consuming and costly }\end{array}$ & $\begin{array}{l}\text { Common EU rules for biobanking in academic clinical } \\
\text { studies (solved in new EU ruling) }\end{array}$ & $\begin{array}{l}\text { Develop stringent site selection criteria a priori } \\
\text { Provide clinical research assistance in countries with high } \\
\text { patient volume but little clinical trial experience } \\
\text { Use pre-existing network } \\
\text { Country-specific variations to be added in a national } \\
\text { addendum to the protocol Protocol harmonisation for all } \\
\text { EU countries } \\
\text { International EU guidelines for trial insurance }\end{array}$ \\
\hline Abbreviation: EU= European Union. & $\begin{array}{l}\text { Serious adverse event regulations vary as a function } \\
\text { of interventional/ non-interventional definition }\end{array}$ \\
High inter centre variability in cost &
\end{tabular}

\section{Table 2. Site-specific logistics in different European countries}

\begin{tabular}{|c|c|c|c|}
\hline & Challenges & Specific challenges & Recommendations \\
\hline $\begin{array}{l}\text { Management of } \\
\text { clinical study }\end{array}$ & $\begin{array}{l}\text { Clinical trial } \\
\text { management } \\
\text { structures }\end{array}$ & $\begin{array}{l}\text { Centre specific variations in experience in international trial } \\
\text { conduct. Difficulty to recruit experienced clinical trial support } \\
\text { personnel in a short period of time, for a defined and limited } \\
\text { time span }\end{array}$ & $\begin{array}{l}\text { Mitigating workload between national and international } \\
\text { clinical trials support structures }\end{array}$ \\
\hline Clinical readout & $\begin{array}{l}\text { MRI: objective } \\
\text { endpoint }\end{array}$ & $\begin{array}{l}\text { Cost of optimal imaging techniques which are not routinely } \\
\text { performed in all participating countries but mandatory for } \\
\text { evaluation of primary endpoint }\end{array}$ & $\begin{array}{l}\text { Discuss shared cost basis with health insurance in an } \\
\text { academic clinical trial involving biobanking without } \\
\text { investigational new reagent }\end{array}$ \\
\hline
\end{tabular}

Site-specific logistics in different European countries. Routine biobanking with clinical annotation and SOPs for tissue handling is relatively new for most sites, and takes time to set-up and to make it efficient (Table 2). BIO-RAIDs identified the following issues that might cause delays: site-specific logistics; organisational issues, such as the availability of experienced investigational personnel; access to liquid nitrogen, and sampling logistics; and the quite variable experience of each site in terms of conducting clinical trials. In some countries, imaging procedures for staging, such as MRI, mandatory to assess a primary endpoint of response to standard therapy were not routinely available. The lack of cohesion between regional and national requirements for imaging type 
(CT rather than MRI) at some sites became apparent when the BIO-RAIDs study began.

Recommendations for improving site-specific logistics. Although an evaluation of study feasibility must focus on the availability of dedicated management personnel who can coordinate logistics and facilitate local management of the study, it must also investigate sites that have a high patient recruitment potential but few or absent dedicated management personnel. We recommend that sites strive to hire experienced management staff in sufficient numbers and train local staff. If this cannot be achieved, regardless of the reasons, the site should be barred from participation until its issues can be resolved.

Site performance is also largely dependent on the principal investigator's (PI's) dedication and availability. If the PI moves to a different workplace or is unavailable for a protracted time, it can jeopardise patient recruitment and the ability of the site to conduct the study. Both the PI and an actively participating proxy should be involved in the trial from the start. If biobanking with clinical annotation is new or relatively new to a site that is otherwise experienced in clinical trial conduct, we advise sending experienced staff to the specific site to assist with the initial set-up and to provide tools for handling biobanking. Finally, international TripAdvisor-like public ratings of site performance might help facilitate necessary changes and improvements.

Collection and monitoring of clinical data and samples. A number of prognostic factors have been put forward for CC (Monk et al, 2007; Rose et al, 2015; Pelkofski et al, 2016), virtually all data have been identified retrospectively, often from small patient populations (Table 3). The prospective assessment of prognosis allowing the comparison of lifestyle and clinical parameters with molecular patterns and outcome is of great interest to clinicians. This prompted us to develop an electronic case report form (eCRF) that required a major effort from clinicians and clinical trial investigators to (a) gather and fill in the data and (b) to control the data in source documents. Our initial version of the eCRF turned out not to be sufficiently user friendly for clinicians and clinical monitoring personnel and needed to be simplified.

In an attempt to reduce shipping costs, barcoded samples were sent in small batches to national referral centres, reviewed for missing samples and sent on in larger batches to the reference laboratory.

With over 400 patients registered at the time of submission, more than 5000 samples consisting of tumour (fixed and frozen) at baseline (and in case of residual tumour or progressive disease secondary biopsies at a later stage) together with whole blood, serum (baseline, post treatment, and 6 monthly) have been at this point transferred to a centralised laboratory at Erasmus, Rotterdam for quality control (QC). QC reviewed pathological diagnosis and evaluated tumour cellularity ( $>30 \%$ for full exome, $10-30 \%$ for targeted panel) from the first and last slice of each set of tissue slices sent for molecular assessment.

All errors which occurred were human errors, the most serious one being a mislabelling by the carrier company, sending a batch to the wrong country. The late recognition of errors (inversion of labels for blood and serum) proved labour-intensive to correct. A central integration platform in knowledge data integration (KDI) at Institut Curie continuously checks for incoherences in the data, sending out reports to all laboratories and clinical monitoring groups. Incoherence in sample ID is checked first. The EAN-13 barcoding scheme was used for sample labelling in the BIO-RAIDS study. Although this format includes a built-in error-checking capability, it could only code for numeric values. Thus, when these barcoded sample IDs are imported into spreadsheet software such as Libre Office or Microsoft Office or into the R statistical computing environment, the 13 digit barcodes are routinely recognised as huge numeric values and are transformed into floating point numbers (for instance, 9110351350145 may be converted to $9.110351 \mathrm{e}+12$ on import). Although it is possible to circumvent this ID corruption in all of the relevant software products, the import of EAN-13 barcodes that only contains digits still requires special attention. Data import issues related to the EAN-13 barcodes can easily be avoided by using both letters and digits. Such 'import-safe' barcodes require appropriate symbology, for example, code 128 that can encode all 128 ASCII characters while offering a built-in checksum system similar to that of EAN-13.

Incoherencies in sample preparation (fixed instead of frozen) or tissue type (tumour, formalin-fixed paraffin-embedded (FFPE), and serum) could be corrected by inspection since the colour of the material in the tube allows to distinguish between FFPE fixed tumour and serum; equally blood and serum are distinguishable by inspection. We implemented a monthly report allowing highlighting the incoherences and making the necessary corrections. The only way to control the biobanking common information was to cross-check the biobanking annotations of sample ID and data of sampling used in each platform against information received from Erasmus and Quanticsoft.

Recommendations for timely sampling and for controlling sampling logistics and clinical data. For effective biobanking (that is, sample handling, shipping, and storage), we feel that sample sets from each patient should ideally be sent promptly to a fully accredited central biobank that will check that the sample is present and send a feedback on the quality of each sample in real time. The biobank should send out electronic alerts to centres when repeat sampling procedures are coming up with copies to the clinical monitoring personnel. Yet this needs to be cautiously evaluated in terms of costs.

Clinical data collection and monitoring tasks can be simplified if we adhere to the following principles. First, the data to be collected should be limited to data relevant for evaluating the study

Table 3. Collection and monitoring of clinical data and samples

\begin{tabular}{|l|l|l|l|}
\hline & Challenges & Specific challenges & Recommendations \\
\hline Biobanking & $\begin{array}{l}\text { Logistics of tissue } \\
\text { sampling and SOPs }\end{array}$ & $\begin{array}{l}\text { Logistics of sites: regular supply of liquid nitrogen, tubes, } \\
\text { trained personnel, control of temperatures, and } \\
\text { traceability }\end{array}$ & $\begin{array}{l}\text { Provide all clinical centres with barcode readers. } \\
\text { Regular visits to sites and extensive control checks on samples. } \\
\text { Regular monthly teleconferences to inform on progress. } \\
\text { Develop international network of integrated ISO labelled } \\
\text { biobanks with clinical support structure } \\
\text { eCRF development to involve information technology } \\
\text { developer, clinicians, scientists and clinical research } \\
\begin{array}{l}\text { Management } \\
\text { of clinical study }\end{array}\end{array}$ \\
$\begin{array}{l}\text { Barcode design } \\
\text { and eCRF capture } \\
\text { Liquid biopsy }\end{array}$ & $\begin{array}{l}\text { Information extraction for sample(s) and traceability } \\
\text { during shipment }\end{array}$ & $\begin{array}{l}\text { of user-friendly electronic tools } \\
\text { Electronic recall in anticipation of repeat sampling by pop } \\
\text { up window in eCRF and in electronic patient file }\end{array}$ \\
\hline Abbreviations: eCRF = electronic case report; SOP=standard operating procedures. & $\begin{array}{l}\text { Regular } 6 \text { monthly serum sampling needed for efficient } \\
\text { statistical assessment of relevance to outcome }\end{array}$ & \\
\hline
\end{tabular}


objectives. Second, the data should be captured in real time using a validated, user friendly eCRF to facilitate flawless data collection and integration. Third, the accuracy, completeness, and coherence of the entered data should be assured through eCRF internal controls. This allows a considerable reduction in on-site monitoring time and therefore a reduction in monitoring costs. The eCRF should include an interactive biobanking section that is accessible to and completed by the clinical centres as well as by the central molecular laboratories to ensure traceability and future use of samples in subsequent ancillary studies. WEBTRIAL was used for the BIO-RAIDs study. Many other easy-to-use eCRF backbones are available today, such as Marvin, REDcap, which is a free, webbased, user friendly electronic data capture (EDC) tool for research studies. The monitoring strategy should ideally be described in the monitoring plan, and significant steps that are meant to reduce the cost of monitoring should be considered. It is currently estimated that the use of complete source data verification will not necessarily result in a substantial improvement in study data. Rather, a riskbased approach for QC, including on-site monitoring, should focus on the study procedures and data, which are relevant for patient safety and data integrity. The following suggestions by Messenger et al (2012) might be worth exploring further: (1) issue a QC report for the data; (2) have a set of internal quality-assurance controls embedded in the eCRF; and (3) institute a yearly data audit programme that includes biobanking information that can be applied to non-interventional studies. Finally, the QC and monitoring strategies should be discussed initially with all participating partners, for example, with clinicians, data management personnel, and biostatisticians.

\section{Optimal sampling and choice of molecular technologies}

Sampling procedures. A variety of challenges are associated with the molecular screening of solid tumours, the first being the collection of adequate samples for the selected molecular technique which dictates the specific handling of tissue samples (Table 4). Cervical tumours are generally easier to access than other cancers, but it should be kept in mind that all biopsies are just a fragment of an observed lesion. Therefore a single tumour biopsy sample is likely to grossly underestimate intra-tumour heterogeneity (Gerlinger et al, 2012; Swanton, 2012). Conversely, a mutational signal can be difficult to detect due to normal tissue 'contamination' that may be present in greater amounts than the tumour cells. Central pathology review appears mandatory. At the reference lab a well-trained technician and a qualified pathologist routinely check, next to histology, the percentage of tumour cells in each biopsy. For this, morphology is taken into account, meaning that next to the percentage of tumour cells the contribution of the infiltrating cells are taken into account resulting in a weighted estimate of the percentage of tumour cells for DNA analyses. Cut offs of $<10 \%, 10-30 \%$, and $>30 \%$ are used.

Molecular analysis techniques. A number of techniques can be used to assess DNA, RNA, and protein alterations in cancer. Our goal was to use validated assays that give reproducible results which lead to treatment recommendations (Le Tourneau et al, 2016). BIO-RAIDs assesses several such techniques. (1) Genetic alterations (genomics) were investigated using next generation sequencing (NGS; full exome of 100 patients), and the resulting information was used to design and utilise a specific targeted panel of genes for the remaining patients. (2) Specific protein pathway activation (proteomics) was detected using reverse-phase protein arrays (RPPAs), and (3) the tumour immune cell and microenvironment interactions were investigated using immunohistochemistry (IHC). (4) There is a need for the development of 'liquid' biopsies and for the detection of surrogate biomarkers; therefore we assessed circulating free DNA (cfDNA) levels and dedicated mutations and HPV insertions. Circulating tumour cells are shed into the bloodstream and can be detected with several technologies (Alix-Panabieres and Pantel, 2014). (5) RNA-based tests (transcriptomics) were not deemed feasible due to their higher cost and because targeted drugs are more likely to act on protein targets. However, residual frozen tissue samples are stored in a dedicated biobank to allow academic RNA-based or epigenetic studies to be conducted in the future.

Finally, of the multiple NGS techniques that are currently available, whole-genome sequencing probably represents the most comprehensive strategy for tumour genomic analysis. Due to high costs and the current long turnaround time, its routine clinical use remains limited. Whole-exome sequencing (WES) appears to be a

Table 4. Optimal sampling and choice of molecular technologies

\begin{tabular}{|c|c|c|c|}
\hline Challenges & Field & Specific challenges & Recommendations \\
\hline $\mathrm{QC}$ & Pathology & $\begin{array}{l}>30 \% \text { tumour cells: sample is suitable to be } \\
\text { assessed by full exome/genome sequencing } \\
\text { and by RPPA } \\
<30 \% \text { of tumour cells: sample can still be } \\
\text { assessed by targeted gene analysis }\end{array}$ & $\begin{array}{l}\text { Compare results of key genetic alterations by full } \\
\text { exome and targeted analyses for their value in } \\
\text { predicting standard and innovative treatment } \\
\text { outcome }\end{array}$ \\
\hline $\begin{array}{l}\text { Rapid changes in } \\
\text { sequencing technologies: }\end{array}$ & Solid vs Illumina technology & $\begin{array}{l}\text { Library generation kits, sequencing kits are } \\
\text { constantly developed by manufacturers. } \\
\text { Updated kits are not } 100 \% \text { compatible with } \\
\text { previous releases and may introduce technical } \\
\text { bias to the data }\end{array}$ & $\begin{array}{l}\text { Careful selection of platforms and kits to avoid } \\
\text { introducing technological heterogeneity } \\
\text { Identification and removal of any version- } \\
\text { dependent technical bias on the data set }\end{array}$ \\
\hline Proteomics & $\begin{array}{l}\text { RPPA captures information on } \\
\text { phosphorylated proteins } \\
\text { retrospectively on complete } \\
\text { data set }\end{array}$ & $\begin{array}{l}\text { Of high interest in clinical trials but not useful } \\
\text { for decision making in real time }\end{array}$ & $\begin{array}{l}\text { Integration with genomic data, development of } \\
\text { suitable routine techniques (ELISA and IHC) for } \\
\text { prospective assessment of markers discovered } \\
\text { by RPPA }\end{array}$ \\
\hline $\begin{array}{l}\text { HPV serotypes and HPV } \\
\text { host integration sites }\end{array}$ & $\begin{array}{l}\text { Action mechanism and } \\
\text { precise HPV contribution to } \\
\text { genetic reshuffling and } \\
\text { tumourigenesis }\end{array}$ & $\begin{array}{l}\text { Integration site assessment by DIPS-PCR is } \\
\text { limited to HPV16 and HPV18 tumours only } \\
\text { Illumina sequencing permits integration } \\
\text { studies of all HPV types }\end{array}$ & $\begin{array}{l}\text { Compare both HPV integration site and HPV E7 } \\
\text { sequence detection as markers and define which } \\
\text { one is the most sensitive }\end{array}$ \\
\hline
\end{tabular}


far more practical technique for routine clinical use, and WES has been incorporated into patient selection strategies in clinical trials (Roychowdhury and Chinnaiyan, 2014; Beltran et al, 2015). WES was selected for use in the BIO-RAIDs study $(n=100)$ to prospectively evaluate very diverse alterations, ranging from point mutations to whole chromosomal rearrangements, and to detect less frequent alterations that are relevant to patient outcome. BIORAIDs is developing targeted exome sequencing of a panel of genes that were chosen because they harbour hotspot mutations according to both our own WES data and according to the literature. Such a targeted panel offers several advantages; in particular, it is cost- and time-effective, and it has manageable bioinformatics and computational requirements (Roychowdhury and Chinnaiyan, 2014; Dietel et al, 2015).

Sequencing instruments, library preparation kits, sequence kits, and analytical tools are in constant development and are likely to change during the course of a multi-year study. For example, the Solid platform, which was the platform of choice during early BIO-RAIDs discussions, had become obsolete by the time the first patient samples were available. Thus, a series of adaptations had to be made to the technical platform. In addition, once the migration to the HiSeq Sequencing Systems was complete, Illumina released a novel sequencing chemistry, V4, that could handle more sequences per run and that had a longer read length. However, detailed QC assessment later revealed that the 125-bp V4 reads tended to show a sharp drop in sequencing quality in the last $10-15$-bp regions, while the 100 -bp reads using the previous V3 chemistry were much less affected by this phenomenon. The effect of the drop in the quality of V4 reads on the downstream analyses (such as somatic variant calling, copy number estimations) is still under investigation and requires changes in the computational pipelines.

Proteomics studies are needed to assess the functional relevance of mutated genes that are identified by genomics technologies. Proteins are highly dynamic molecules and are subject to extensive functional regulation, most notably by post-translational modifications. In-depth studies of proteomic profiles will help us understand CC tumour pathogenesis more comprehensively and could lead to the identification of novel biomarkers and cancer therapy targets (Sallam, 2015). RPPA is a high-throughput dot-blot technology with two major advantages: first, it compares hundreds of biopsies simultaneously on the same array; second, it requires only small amounts of tissue. RPPA is therefore currently the method of choice for retrospective targeted analysis of biopsies. However, it is less well suited for prospective patient investigation for clinical decision-making. Furthermore, RPPA technology is targeted and therefore relies on the availability of high-quality antibodies. The percentage of tumour cells in the tissue is also a real issue. Laser capture microdissection can be used to enrich tumour regions, but this is time-consuming and substantially reduces the throughput. Finally, since post-translational modification is highly dynamic and unstable, the freezing, storage, and shipment conditions must be carefully controlled.

Immunohistochemistry provides a robust view of intra-tumour heterogeneity and is crucial for confirming the genomic alterations that are identified during genomic analyses. Furthermore, IHC is useful for studying the interactions between tumour cells and the host immune system. Unfortunately, standard chromogenic IHC has inter-assay variability, so quantifying the results is difficult. The main hurdle associated with IHC is linked to sample processing in that the tissue must be adequately fixed in formalin. In addition, standard IHC techniques are limited to the use of one specific antibody of interest, and different laboratories use different antibody clones.

Recommendations for tumour sampling and molecular techniques. One key issue in the selection of the best analytical technique is the availability of the appropriate type of sample, that is, tumour (fresh, frozen, or fixed), blood, or plasma.

Analysing multiple tumour biopsies from different sites is ideal, but can be logistically challenging. To ensure best quality sample for nucleic acid extraction procedures, one or more samples must be snap-frozen in liquid nitrogen and stored until analysis. The other samples must be quickly fixed in neutral-buffered formalin for pathological and molecular analyses. The aim should be to keep a mirror FFPE tumour block of the tumour area from which a frozen sample has been taken. Furthermore, a frozen sample of peri-tumoural normal tissue should also be obtained.

Molecular results are used to make treatment decisions and, consequently, are subject to legal obligations that are designed so that the tests are reproducible and adhere to high standards ensuring sensitivity and specificity. Molecular platforms therefore need to be validated. Despite the lack of clear guidelines, FDAcertified platforms in the USA and ISO-certified platforms in Europe are being developed (McShane et al, 2013).

To minimise the risk of technical bias in the data set, it is highly desirable that every sample be processed using exactly the same kits and methods. If the logistics and the project timing allows it, and if the necessary instruments are available, it seems worthwhile to first gradually collect the complete set of qualitycontrolled DNA/RNA samples and then later to process them all within a single wet lab project to ensure identical kit versions for all of the analyses.

NGS or targeted digital PCR of cfDNA can be used to identify changes in the tumour mutational landscape, and cfDNA can be detected in the absence of CTCs (Bettegowda et al, 2014). Targeted sequencing of cfDNA can detect driver mutations at low allele frequencies with high sensitivity (Frenel et al, 2015). Such findings could allow treatment monitoring and early detection of resistant mutations before radiological signs of disease progression (Oxnard et al, 2014). Notably, cfDNA can also be detected in other body fluids, like saliva and urine (Janku et al, 2014; Wang et al, 2015). Using NGS to detect circulating cfDNA, it is possible to indirectly track tumour progression; moreover, mutations that were identified in the tumour can be detected with a simple blood sample (Lebofsky et al, 2015; Lianos et al, 2015). Since cfDNA can originate from either the primary tumour or from a metastatic site, it serves as a 'liquid biopsy' that reflects the genetic heterogeneity of a patient and could potentially identify putative targets for therapy. cfDNA also represents a way to monitor genetic heterogeneity during treatment in a non-invasive manner. A recent paper supports this, describing how diverse cancers show detectable ctDNA alterations, with the majority being theoretically actionable by approved agents (Schwaederle et al, 2016).

To reliably analyse protein modifications, the biopsy must be flash-frozen in liquid nitrogen, ideally on-site at each clinical centre. When there is no high-quality antibody available for a protein of interest, a protein downstream in the same signalling pathway can be utilised as a surrogate marker. Epithelial cell and immune cell infiltrate markers can be added to the analysis and might give a rough estimation of tumour content that can be compared with the pathology results. In the future, other technologies that overcome the difficulties of RPPA might be sufficiently improved and affordable that they could be used in clinical studies. Notably, rapid advances are being made in the field of mass spectrometry, but data interpretation remains a challenge, and large amounts of tissue are required to analyse the phosphoproteome.

For IHC analyses, the development of technical SOPs, the use of validated antibody clones, and specifically the use of (semi-) automated systems will enable quantitative pathology assessments. This field is currently taking a huge leap forward due to advances in digital pathology and due to the rapid development of 
Table 5. Challenges in $\mathrm{QC}$, data integration and data analysis

\begin{tabular}{|c|c|c|c|}
\hline & Challenges & Specific challenges & Recommendations \\
\hline $\begin{array}{l}\text { Biobank quality } \\
\text { analysis }\end{array}$ & Sample or data mixup & $\begin{array}{l}\text { Mixup can occurr at any step with a potential to falsify data. } \\
\text { (for example, error in barcode sticker, in date in eCRF as } \\
\text { compared with source data, laboratory mixup etc.) }\end{array}$ & $\begin{array}{l}\text { Check for cross-contamination in each sample } \\
\text { and test for proper clustering of matched samples. } \\
\text { Clean and reliable data to be shared with other } \\
\text { platforms }\end{array}$ \\
\hline $\begin{array}{l}\text { Full exome } \\
\text { sequencing }\end{array}$ & $\begin{array}{l}\text { Variant calling and } \\
\text { gene copy number }\end{array}$ & $\begin{array}{l}\text { Choice of filters for variant callers and variant calling } \\
\text { parameters greatly influences the position of reported } \\
\text { variants in list of frequency }\end{array}$ & $\begin{array}{l}\text { Establish a gold-standard variant caller pipeline that } \\
\text { shall be applied on all samples }\end{array}$ \\
\hline $\begin{array}{l}\text { Complex data } \\
\text { integration }\end{array}$ & $\begin{array}{l}\text { Clinical and molecular } \\
\text { data integration }\end{array}$ & Bridge clinical with molecular data & $\begin{array}{l}\text { Implement of seemless integrating system } \\
\text { (ex. KDI TranSmart ...) }\end{array}$ \\
\hline
\end{tabular}

simultaneous multispectral analysis of many different markers in one small biopsy, which will ultimately lead to its implementation in day-to-day pathology practice (Feng et al, 2015). Therefore, objective, high-throughput biomarker quantification and co-localisation using multiplexed IHC will aid in the future selection of patients that might benefit from specific treatment (Huang et al, 2013; Dixon et al, 2015).

Challenges in QC, data integration, and data analysis. Rapid advances in technology have decreased costs and improved throughput, allowing the collection of vast amounts of 'omics' information in cancer (Table 5). However, robust and reproducible bioinformatics tools that can be used to interpret these data are still being developed. NGS has paved the way for precision medicine in the field of oncology. The lower laboratory sequencing costs of NGS caused an exponential increase in the amount of data produced, putting a large strain on data managers and bioinformatics engineers who were called on to manage all of this information (Simon and Roychowdhury, 2013). Collectively, NGS and 'omics' techniques have huge potential for clinical applications, but the techniques and tools are constantly developing. The availability of high-throughput technologies dedicated to clinical applications makes them very attractive for daily use in cancer centres. However, establishing these clinical facilities is not a trivial task due to the overwhelming amount of data. There are three challenges in extracting most of the relevant biological and clinical information from these data: (1) developing sufficiently powerful computational architecture (software/hardware); (2) establishing the organisational and management structure that is needed to define the procedures for collecting high-quality data that is reliable and traceable; and (3) developing scientific expertise to create sophisticated mathematical models that can predict the evolution of the disease and the risks to the patient (Barillot et al, 2012).

Bioinformatics data analysis and recommendations for future clinical data architecture. Clearly efficient informatics and bioinformatics architecture is needed to support precision medicine to record, manage, and analyse all of the collected information. The architecture must also allow queries and the easy retrieval of data that might be useful, either now or in the future, for real-time therapeutic decisions so that clinicians can propose tailored therapy to the patient without delays. Accordingly, bioinformatics is among the most important bottlenecks in the routine application of precision medicine. Several challenges must be overcome to make precision medicine a reality. First, a seamless information system must be developed that allows data integration, data traceability, and knowledge sharing across the different stakeholders. Second, bioinformatics pipelines need to be developed to make relevant biological information from the highthroughput molecular profiles of the patient rapidly available to clinicians. Third, the architecture must ensure the reproducibility of the results. All of these bioinformatics challenges were reviewed by Servant et al (2014). At the Institut Curie, in the context of the RAIDs project, a information system termed KDI (for 'knowledge and data integration') was set-up to ensure the sharing of information between partners, cross-software interoperability, automatic data extraction, and secure data transfer. Other similar systems are available today, such as the tranSMART platform, which is an open-source, community-driven knowledge management platform for translational medicine (Barash et al, 2015).

\section{CONCLUSION}

In the era of precision medicine the numbers of biobanking studies are increasing and raise several issues. The BIO-RAIDs study identified challenges associated with the practical aspects of systematic biobanking that lead to delays in clinical trial initiation. To address these challenges, there needs to be increased cooperation and standardisation in terms of regulatory rules and practices across the EU. Although most errors are human errors and related to initial handling, there is a need for teaching courses for best-practice biobanking techniques standards and QC aspects. On another level there is a need for a better understanding by clinicians and by drug manufacturers of the technical and bioinformatics analytical skills needed to improve decision-making in the field of precision medicine. Although BIO-RAIDs is purely an analytical trial, it sets the stage for future clinical trials of specifically targeted drugs or drug cocktails. Ongoing work on cell lines that compares mutational and proteomics data with pharmacological profiling should help identify common targeted drugs and drug cocktails that benefit patients. In addition to these technical and clinical research aspects, the perception of patients and their feedback on biobanking is key. A recent study shows that patients are receptive to donate tissue samples if they are educated on the importance of specimen based research (Braun et al, 2014), an observation that seems to be shared in the BioRaids population.

\section{ACKNOWLEDGEMENTS}

We would like to thank all of the RAIDs consortium members for their concerted efforts in conducting the BIO-RAIDs trial. A special thank you to Dr P Ewing-Graham (Department of Pathology, Rotterdam) for her expert pathological review. This project received funding from the European Union's Seventh Program for Research, Technological Development, and Demonstration (grant no. 304810).

\section{CONFLICT OF INTEREST}

The authors declare no conflict of interest. 


\section{REFERENCES}

Alix-Panabieres C, Pantel K (2014) Challenges in circulating tumour cell research. Nat Rev Cancer 14: 623-631.

Barash CI, Elliston K, Potenzone R (2015) TranSMART Foundation Datathon 1.0: the cross neurodegenerative diseases challenge. Appl Transl Genom 6: 42-44.

Barillot E, Calzone L, Hupe P, Vert J, Zinovyev A (2012) Computational Systems Biology of Cancer. CRC Press.

Beltran H, Eng K, Mosquera JM, Sigaras A, Romanel A, Rennert H, Kossai M, Pauli C, Faltas B, Fontugne J, Park K, Banfelder J, Prandi D, Madhukar N, Zhang T, Padilla J, Greco N, McNary TJ, Herrscher E, Wilkes D, MacDonald TY, Xue H, Vacic V, Emde AK, Oschwald D, Tan AY, Chen Z, Collins C, Gleave ME, Wang Y, Chakravarty D, Schiffman M, Kim R, Campagne F, Robinson BD, Nanus DM, Tagawa ST, Xiang JZ, Smogorzewska A, Demichelis F, Rickman DS, Sboner A, Elemento O, Rubin MA (2015) Whole-exome sequencing of metastatic cancer and biomarkers of treatment response. JAMA Oncol 1: 466-474.

Bettegowda C, Sausen M, Leary RJ, Kinde I, Wang Y, Agrawal N, Bartlett BR, Wang H, Luber B, Alani RM, Antonarakis ES, Azad NS, Bardelli A, Brem H, Cameron JL, Lee CC, Fecher LA, Gallia GL, Gibbs P, Le D, Giuntoli RL, Goggins M, Hogarty MD, Holdhoff M, Hong SM, Jiao Y, Juhl HH, Kim JJ, Siravegna G, Laheru DA, Lauricella C, Lim M, Lipson EJ, Marie SK, Netto GJ, Oliner KS, Olivi A, Olsson L, Riggins GJ, Sartore-Bianchi A, Schmidt K, Shih IM, Oba-Shinjo SM, Siena S, Theodorescu D, Tie J, Harkins TT, Veronese S, Wang TL, Weingart JD, Wolfgang CL, Wood LD, Xing D, Hruban RH, Wu J, Allen PJ, Schmidt CM, Choti MA, Velculescu VE, Kinzler KW, Vogelstein B, Papadopoulos N, Diaz LA Jr (2014) Detection of circulating tumor DNA in early- and late-stage human malignancies. Sci Transl Med 6: 224ra24.

Braun K, Tsark JU, Powers A, Croom K, Kim R, Gachupin FC, Morris P (2014) Cancer patient perception about biobanking and preferred timing of consent. Biopreserv Biobank 12: 106-112.

Diaz Z, Aguilar-Mahecha A, Paquet ER, Basik M, Orain M, Camlioglu E, Constantin A, Benlimame N, Bachvarov D, Jannot G, Simard MJ, Chabot B, Gologan A, Klinck R, Gagnon-Kugler T, Lespérance B, Samson B, Kavan P, Alcindor T, Dalfen R, Lan C, Chabot C, Buchanan M, Przybytkowski E, Qureshi S, Rousseau C, Spatz A, Têtu B, Batist G (2013) Next-generation biobanking of metastases to enable multidimensional molecular profiling in personalized medicine. Mod Pathol 26: 1413-1424.

Dietel M, Johrens K, Laffert MV, Hummel M, Blaker H, Pfitzner BM, Lehmann A, Denkert C, Darb-Esfahani S, Lenze D, Heppner FL, Koch A, Sers C, Klauschen F, Anagnostopoulos I (2015) A 2015 update on predictive molecular pathology and its role in targeted cancer therapy: a review focussing on clinical relevance. Cancer Gene Ther 22: 417-430.

Dixon AR, Bathany C, Tsuei M, White J, Barald KF, Takayama S (2015) Recent developments in multiplexing techniques for immunohistochemistry. Expert Rev Mol Diagn 15: 1171-1186.

Feng Z, Puri S, Moudgil T, Wood W, Hoyt CC, Wang C, Urba WJ, Curti BD, Bifulco CB, Fox BA (2015) Multispectral imaging of formalin-fixed tissue predicts ability to generate tumor-infiltrating lymphocytes from melanoma. J Immunother Cancer 3: 47.

Ferlay J, Soerjomataram I, Dikshit R, Eser S, Mathers C, Rebelo M, Parkin DM, Forman D, Bray F (2015) Cancer incidence and mortality worldwide: sources, methods and major patterns in GLOBOCAN 2012. Int J Cancer 136: E359-E386.

Frenel JS, Carreira S, Goodall J, Roda D, Perez-Lopez R, Tunariu N, Riisnaes R, Miranda S, Figueiredo I, Nava-Rodrigues D, Smith A, Leux C, Garcia-Murillas I, Ferraldeschi R, Lorente D, Mateo J, Ong M, Yap TA, Banerji U, Gasi Tandefelt D, Turner N, Attard G, de Bono JS (2015) Serial next-generation sequencing of circulating cell-free DNA evaluating tumor clone response to molecularly targeted drug administration. Clin Cancer Res 21: 4586-4596.

Furue M, Kadono T (2016) Melanoma therapy: check the checkpoints. J Dermatol 43: 121-124.

Gerlinger C, Edler L, Friede T, Kieser M, Nakas CT, Schumacher M, Seldrup J, Victor N (2012) Considerations on what constitutes a 'qualified statistician' in regulatory guidelines. Stat Med 31: 1303-1305.

Huang W, Hennrick K, Drew S (2013) A colorful future of quantitative pathology: validation of Vectra technology using chromogenic multiplexed immunohistochemistry and prostate tissue microarrays. Hum Pathol 44: 29-38.

International Cancer Genome C, Hudson TJ, Anderson W, Artez A, Barker AD, Bell C, Bernabe RR, Bhan MK, Calvo F, Eerola I, Gerhard DS,
Guttmacher A, Guyer M, Hemsley FM, Jennings JL, Kerr D, Klatt P, Kolar P, Kusada J, Lane DP, Laplace F, Youyong L, Nettekoven G, Ozenberger B, Peterson J, Rao TS, Remacle J, Schafer AJ, Shibata T, Stratton MR, Vockley JG, Watanabe K, Yang H, Yuen MM, Knoppers BM, Bobrow M, Cambon-Thomsen A, Dressler LG, Dyke SO, Joly Y, Kato K, Kennedy KL, Nicolas P, Parker MJ, Rial-Sebbag E, Romeo-Casabona CM, Shaw KM, Wallace S, Wiesner GL, Zeps N, Lichter P, Biankin AV, Chabannon C, Chin L, Clement B, de Alava E, Degos F, Ferguson ML, Geary P, Hayes DN, Hudson TJ, Johns AL, Kasprzyk A, Nakagawa H, Penny R, Piris MA, Sarin R, Scarpa A, Shibata T, van de Vijver M, Futreal PA, Aburatani H, Bayes M, Botwell DD, Campbell PJ, Estivill X, Gerhard DS, Grimmond SM, Gut I, Hirst M, Lopez-Otin C, Majumder P, Marra M, McPherson JD, Nakagawa H, Ning Z, Puente XS, Ruan Y, Shibata T, Stratton MR, Stunnenberg HG, Swerdlow H, Velculescu VE, Wilson RK, Xue HH, Yang L, Spellman PT, Bader GD, Boutros PC, Campbell PJ, Flicek P, Getz G, Guigó R, Guo G, Haussler D, Heath S, Hubbard TJ, Jiang T, Jones SM, Li Q, López-Bigas N, Luo R, Muthuswamy L, Ouellette BF, Pearson JV, Puente XS, Quesada V, Raphael BJ, Sander C, Shibata T, Speed TP, Stein LD, Stuart JM, Teague JW, Totoki Y, Tsunoda T, Valencia A, Wheeler DA, Wu H, Zhao S, Zhou G, Stein LD, Guigó R, Hubbard TJ, Joly Y, Jones SM, Kasprzyk A, Lathrop M, López-Bigas N, Ouellette BF, Spellman PT, Teague JW, Thomas G, Valencia A, Yoshida T, Kennedy KL, Axton M, Dyke SO, Futreal PA, Gerhard DS, Gunter C, Guyer M, Hudson TJ, McPherson JD, Miller LJ, Ozenberger B, Shaw KM, Kasprzyk A, Stein LD, Zhang J, Haider SA, Wang J, Yung CK, Cros A, Liang Y, Gnaneshan S, Guberman J, Hsu J, Bobrow M, Chalmers DR, Hasel KW, Joly Y, Kaan TS, Kennedy KL, Knoppers BM, Lowrance WW, Masui T, Nicolás P, Rial-Sebbag E, Rodriguez LL, Vergely C, Yoshida T, Grimmond SM, Biankin AV, Bowtell DD, Cloonan N, de Fazio A, Eshleman JR, Etemadmoghadam D, Gardiner BB, Kench JG, Scarpa A, Sutherland RL, Tempero MA, Waddell NJ, Wilson PJ, McPherson JD, Gallinger S, Tsao MS, Shaw PA, Petersen GM, Mukhopadhyay D, Chin L, DePinho RA, Thayer S, Muthuswamy L, Shazand K, Beck T, Sam M, Timms L, Ballin V, Lu Y, Ji J, Zhang X, Chen F, Hu X, Zhou G, Yang Q, Tian G, Zhang L, Xing X, Li X, Zhu Z, Yu Y, Yu J, Yang H, Lathrop M, Tost J, Brennan P, Holcatova I, Zaridze D, Brazma A, Egevard L, Prokhortchouk E, Banks RE, Uhlén M, Cambon-Thomsen A, Viksna J, Ponten F, Skryabin K, Stratton MR, Futreal PA, Birney E, Borg A, Børresen-Dale AL, Caldas C, Foekens JA, Martin S, Reis-Filho JS, Richardson AL, Sotiriou C, Stunnenberg HG, Thoms G, van de Vijver M, van't Veer L, Calvo F, Birnbaum D, Blanche H, Boucher P, Boyault S, Chabannon C, Gut I, Masson-Jacquemier JD, Lathrop M, Pauporté I, Pivot X, Vincent-Salomon A, Tabone E, Theillet C, Thomas G, Tost J, Treilleux I, Calvo F, Bioulac-Sage P, Clément B, Decaens T, Degos F, Franco D, Gut I, Gut M, Heath S, Lathrop M, Samuel D, Thomas G, Zucman-Rossi J, Lichter P, Eils R, Brors B, Korbel JO, Korshunov A, Landgraf P, Lehrach H, Pfister S, Radlwimmer B, Reifenberger G, Taylor MD, von Kalle C, Majumder PP, Sarin R, Rao TS, Bhan MK, Scarpa A, Pederzoli P, Lawlor RA, Delledonne M, Bardelli A, Biankin AV, Grimmond SM, Gress T, Klimstra D, Zamboni G, Shibata T, Nakamura Y, Nakagawa H, Kusada J, Tsunoda T, Miyano S, Aburatani H, Kato K, Fujimoto A, Yoshida T, Campo E, López-Otín C, Estivill X, Guigó R, de Sanjosé S, Piris MA, Montserrat E, González-Díaz M, Puente XS, Jares P, Valencia A, Himmelbauer H, Quesada V, Bea S, Stratton MR, Futreal PA, Campbell PJ, Vincent-Salomon A, Richardson AL, Reis-Filho JS, van de Vijver M, Thomas G, Masson-Jacquemier JD, Aparicio S, Borg A, Børresen-Dale AL, Caldas C, Foekens JA, Stunnenberg HG, van't Veer L, Easton DF, Spellman PT, Martin S, Barker AD, Chin L, Collins FS, Compton CC, Ferguson ML, Gerhard DS, Getz G, Gunter C, Guttmacher A, Guyer M, Hayes DN, Lander ES, Ozenberger B, Penny R, Peterson J, Sander C, Shaw KM, Speed TP, Spellman PT, Vockley JG, Wheeler DA, Wilson RK, Hudson TJ, Chin L, Knoppers BM, Lander ES, Lichter P, Stein LD, Stratton MR, Anderson W, Barker AD, Bell C, Bobrow M, Burke W, Collins FS, Compton CC, DePinho RA, Easton DF, Futreal PA, Gerhard DS, Green AR, Guyer M, Hamilton SR, Hubbard TJ, Kallioniemi OP, Kennedy KL, Ley TJ, Liu ET, Lu Y, Majumder P, Marra M, Ozenberger B, Peterson J, Schafer AJ, Spellman PT, Stunnenberg HG, Wainwright BJ, Wilson RK, Yang H (2010) International network of cancer genome projects. Nature 464: 993-998. Janku F, Vibat CR, Kosco K, Holley VR, Cabrilo G, Meric-Bernstam F, Stepanek VM, Lin PP, Leppin L, Hassaine L, Poole JC, Kurzrock R, Erlander MG (2014) BRAF V600E mutations in urine and plasma cell-free DNA from patients with Erdheim-Chester disease. Oncotarget 5: 3607-3610. 
Jimenez-Wences H, Peralta-Zaragoza O, Fernandez-Tilapa G (2014) Human papilloma virus, DNA methylation and microRNA expression in cervical cancer (Review). Oncol Rep 31: 2467-2476.

Le Tourneau C, Delord JP, Goncalves A, Gavoille C, Dubot C, Isambert N, Campone M, Tredan O, Massiani MA, Mauborgne C, Armanet S, Servant N, Bieche I, Bernard V, Gentien D, Jezequel P, Attignon V, Boyault S, Vincent-Salomon A, Servois V, Sablin MP, Kamal M, Paoletti X. investigators S (2015) Molecularly targeted therapy based on tumour molecular profiling versus conventional therapy for advanced cancer (SHIVA): a multicentre, open-label, proof-of-concept, randomised, controlled phase 2 trial. Lancet Oncol 16: 1324-1334.

Le Tourneau C, Kamal M, Alt M, Verlingue L, Servois V, Sablin MP, Servant N, Paoletti X (2014) The spectrum of clinical trials aiming at personalizing medicine. Chin Clin Oncol 3: 13.

Le Tourneau C, Kamal M, Tsimberidou AM, Bedard P, Pierron G, Callens C, Rouleau E, Vincent-Salomon A, Servant N, Alt M, Rouzier R, Paoletti X, Delattre O, Bieche I (2016) Treatment algorithms based on tumor molecular profiling: the essence of precision medicine trials. J Natl Cancer Inst 108(4): djv362.

Lebofsky R, Decraene C, Bernard V, Kamal M, Blin A, Leroy Q, Rio Frio T, Pierron G, Callens C, Bieche I, Saliou A, Madic J, Rouleau E, Bidard FC, Lantz O, Stern MH, Le Tourneau C, Pierga JY (2015) Circulating tumor DNA as a noninvasive substitute to metastasis biopsy for tumor genotyping and personalized medicine in a prospective trial across all tumor types. Mol Oncol 9: 783-790.

Lianos GD, Mangano A, Cho WC, Dionigi G, Roukos DH (2015) Circulating tumor DNA: new horizons for improving cancer treatment. Future Oncol 11: $545-548$.

Marusyk A, Almendro V, Polyak K (2012) Intra-tumour heterogeneity: a looking glass for cancer? Nat Rev Cancer 12: 323-334.

McGranahan N, Furness AJ, Rosenthal R, Ramskov S, Lyngaa R, Saini SK, Jamal-Hanjani M, Wilson GA, Birkbak NJ, Hiley CT, Watkins TB, Shafi S, Murugaesu N, Mitter R, Akarca AU, Linares J, Marafioti T, Henry JY, Van Allen EM, Miao D, Schilling B, Schadendorf D, Garraway LA, Makarov V, Rizvi NA, Snyder A, Hellmann MD, Merghoub T, Wolchok JD, Shukla SA, Wu CJ, Peggs KS, Chan TA, Hadrup SR, Quezada SA, Swanton C (2016) Clonal neoantigens elicit T cell immunoreactivity and sensitivity to immune checkpoint blockade. Science 351(6280): 1463-1469.

McShane LM, Cavenagh MM, Lively TG, Eberhard DA, Bigbee WL, Williams PM, Mesirov JP, Polley MY, Kim KY, Tricoli JV, Taylor JM, Shuman DJ, Simon RM, Doroshow JH, Conley BA (2013) Criteria for the use of omics-based predictors in clinical trials: explanation and elaboration. BMC Med 11: 220.

Messenger JC, Ho KK, Young CH, Slattery LE, Draoui JC, Curtis JP, Dehmer GJ, Grover FL, Mirro MJ, Reynolds MR, Rokos IC, Spertus JA, Wang TY, Winston SA, Rumsfeld JS, Masoudi FA. Science N, Quality Oversight Committee Data Quality W (2012) The National Cardiovascular Data Registry (NCDR) data quality brief: the NCDR Data Quality Program in 2012. J Am Coll Cardiol 60: 1484-1488.

Monk BJ, Tian C, Rose PG, Lanciano R (2007) Which clinical/pathologic factors matter in the era of chemoradiation as treatment for locally advanced cervical carcinoma? Analysis of two Gynecologic Oncology Group (GOG) trials. Gynecol Oncol 105: 427-433.

Ngo C, Samuels S, Bagrintseva K, Slocker A, Hupe P, Kenter G, Popovic M, Samet N, Tresca P, von der Leyen H, Deutsch E, Rouzier R, Belin L, Kamal M, Scholl S. consortium R (2015) From prospective biobanking to precision medicine: BIO-RAIDs-an EU study protocol in cervical cancer. BMC Cancer 15: 842.

Ojesina AI, Lichtenstein L, Freeman SS, Pedamallu CS, Imaz-Rosshandler I, Pugh TJ, Cherniack AD, Ambrogio L, Cibulskis K, Bertelsen B, Romero-Cordoba S, Trevino V, Vazquez-Santillan K, Guadarrama AS, Wright AA, Rosenberg MW, Duke F, Kaplan B, Wang R, Nickerson E, Walline HM, Lawrence MS, Stewart C, Carter SL, McKenna A, Rodriguez-Sanchez IP, Espinosa-Castilla M, Woie K, Bjorge L, Wik E, Halle MK, Hoivik EA, Krakstad C, Gabino NB, Gomez-Macias GS, Valdez-Chapa LD, Garza-Rodriguez ML, Maytorena G, Vazquez J, Rodea C, Cravioto A, Cortes ML, Greulich H, Crum CP, Neuberg DS, Hidalgo-Miranda A, Escareno CR, Akslen LA, Carey TE, Vintermyr OK, Gabriel SB, Barrera-Saldana HA, Melendez-Zajgla J, Getz G, Salvesen HB,
Meyerson M (2014) Landscape of genomic alterations in cervical carcinomas. Nature 506: 371-375.

Oxnard GR, Paweletz CP, Kuang Y, Mach SL, O'Connell A, Messineo MM, Luke JJ, Butaney M, Kirschmeier P, Jackman DM, Janne PA (2014) Noninvasive detection of response and resistance in EGFR-mutant lung cancer using quantitative next-generation genotyping of cell-free plasma DNA. Clin Cancer Res 20: 1698-1705.

Pelkofski E, Stine J, Wages NA, Gehrig PA, Kim KH, Cantrell LA (2016) Cervical cancer in women aged 35 years and younger. Clin Ther 38(3): 459-466.

Prasad V (2016) Perspective: The precision-oncology illusion. Nature 537(7619): S63.

Riondino S, Ferroni P, Spila A, Alessandroni J, D’Alessandro R, Formica V, Della-Morte D, Palmirotta R, Nanni U, Roselli M, Guadagni F (2015) Ensuring sample quality for biomarker discovery studies-use of ICT tools to trace biosample life-cycle. Cancer Genom Proteom 12: 291-299.

Rose PG, Java J, Whitney CW, Stehman FB, Lanciano R, Thomas GM, DiSilvestro PA (2015) Nomograms predicting progression-free survival, overall survival, and pelvic recurrence in locally advanced cervical cancer developed from an analysis of identifiable prognostic factors in patients from NRG oncology/gynecologic oncology group randomized trials of chemoradiotherapy. J Clin Oncol 33: 2136-2142.

Roychowdhury S, Chinnaiyan AM (2014) Translating genomics for precision cancer medicine. Annu Rev Genomics Hum Genet 15: 395-415.

Rusan M, Li YY, Hammerman PS (2015) Genomic landscape of human papillomavirus-associated cancers. Clin Cancer Res 21: 2009-2019.

Sallam RM (2015) Proteomics in cancer biomarkers discovery: challenges and applications. Dis Markers 2015: 321370.

Scholl SM, Kamal M, De Koning L, Kereszt A, Jordanova ES, Ungureanu S, Berns E, Sastre X (2013) HPV pathway profiling: HPV related cervical dysplasia and carcinoma studies. Curr Pharm Des 19: 1379-1394.

Schwaederle M, Husain H, Fanta PT, Piccioni DE, Kesari S, Schwab RB, Banks KC, Lanman RB, Talasaz A, Parker BA, Kurzrock R (2016) Detection rate of actionable mutations in diverse cancers using a biopsy-free (blood) circulating tumor cell DNA assay. Oncotarget 7(9): 9707-9717.

Schwarz JK, Payton JE, Rashmi R, Xiang T, Jia Y, Huettner P, Rogers BE, Yang Q, Watson M, Rader JS, Grigsby PW (2012) Pathway-specific analysis of gene expression data identifies the PI3K/Akt pathway as a novel therapeutic target in cervical cancer. Clin Cancer Res 18: 1464-1471.

Servant N, Romejon J, Gestraud P, La Rosa P, Lucotte G, Lair S, Bernard V, Zeitouni B, Coffin F, Jules-Clement G, Yvon F, Lermine A, Poullet P, Liva S, Pook S, Popova T, Barette C, Prud'homme F, Dick JG, Kamal M, Le Tourneau C, Barillot E, Hupe P (2014) Bioinformatics for precision medicine in oncology: principles and application to the SHIVA clinical trial. Front Genet 5: 152.

Simon R, Roychowdhury S (2013) Implementing personalized cancer genomics in clinical trials. Nat Rev Drug Discov 12: 358-369.

Spaans VM, Trietsch MD, Peters AA, Osse M, Ter Haar N, Fleuren GJ, Jordanova ES (2015) Precise classification of cervical carcinomas combined with somatic mutation profiling contributes to predicting disease outcome. PLoS One 10: e0133670.

Swanton C (2012) Intratumor heterogeneity: evolution through space and time. Cancer Res 72: 4875-4882.

Wang Y, Springer S, Mulvey CL, Silliman N, Schaefer J, Sausen M, James N, Rettig EM, Guo T, Pickering CR, Bishop JA, Chung CH, Califano JA, Eisele DW, Fakhry C, Gourin CG, Ha PK, Kang H, Kiess A, Koch WM, Myers JN, Quon H, Richmon JD, Sidransky D, Tufano RP, Westra WH, Bettegowda C, Diaz Jr LA, Papadopoulos N, Kinzler KW, Vogelstein B, Agrawal N (2015) Detection of somatic mutations and HPV in the saliva and plasma of patients with head and neck squamous cell carcinomas. Sci Transl Med 7: 293 ra104.

This work is published under the standard license to publish agreement. After 12 months the work will become freely available and the license terms will switch to a Creative Commons AttributionNonCommercial-Share Alike 4.0 Unported License. 